\title{
EVALUASI PROGRAM PEMBINAAN PRESTASI CABANG OLAHRAGA PANAHAN DI BALI
}

\author{
Kadek Dian Vanagosi ${ }^{1}$, Putu Citra Permana Dewi ${ }^{2}$ \\ ${ }^{1,2}$ Program Studi Penjaskesrek, IKIP PGRI Bali \\ Denpasar - Indonesia \\ e-mail : kadekvanagosi@gmail.com, putucitrapermanadewi@gmail.com
}

\begin{abstract}
Abstrak
Penelitian bertujuan untuk mengetahui pelaksanaan program pembinaan prestasi cabang olahraga panahan di Bali dengan pendekatan evaluasi CIPP Model. Subyek penelitian meliputi pengurus, pelatih, atlet, dan masyarakat sekitar Pengkab/Pengkot se-Bali. Instrumen yang digunakan adalah angket dan pedoman wawancara. Didapat hasil pada dimensi konteks bahwa diperlukan adanya kerjasama antara pemerintah daerah dan masyarakat untuk berperan serta aktif dalam mendukung keberadaaan Pengcab Perpani Kabupaten/Kota di Bali sehingga bisa menjadi sentra pembibitan atlet panahan di Bali. Pada dimensi input masuk dalam kategori cukup baik, dimana yang perlu dikembangkan adalah pemenuhan sarana dan prasarana latihan berupa tempat latihan khusus olahraga panahan, peralatan memanah pada masing-masing divisi serta sarana pendukung. Pada dimensi proses, pelaksanaan program mulai dari penyeleksian atlet, pengorganisasian, pelaksanaan latihan, program latihan dan evaluasi/monev masuk dalam kategori cukup baik. Hal yang perlu dikembangkan yaitu peningkatan kualitas pelatih dan wasit melalui penataran pelatihan pelatih dan wasit panahan. Pada dimensi produk, hasil yang didapat dari program pembinaan yang telah dijalankan masih dalam kategori kurang. Hal yang perlu dikembangkan berkaitan dengan perkembangan fisik, teknik, dan mental atlet.
\end{abstract}

Kata-kata kunci : evaluasi, CIPP, pembinaan, panahan

Abstract
The aim of this study was to determine the implementation of the program to improve
the performance of archery in Bali with the Context, Input, Process, Product (CIPP)
Model evaluation approach. The research subjects include administrators, coaches,
athletes, and the community. The instruments used were questionnaires and interview
guidelines.Obtained results on the context dimension that cooperation between the local
government and the community is needed to play an active role in supporting the
existence of the Perpani in Bali, so that it can become a center for archery athletes in
Bali.In the dimension of input included in the fairly good category, what needs to be
developed is the fulfillment of training facilities and infrastructure in the form of
archery-specific training sites, archery equipment in each division and supporting
facilities.In the dimensions of procces, the implementation of the program starting from
selecting athletes, organizing, implementing the exercises, training programs and
evaluating/ monitoring and evaluation is in a fairly good category.Things that need to be
developed are improving the quality of coaches and referees through upgrading the
training of archery coaches and referees. On the product dimension, the results obtained
from the coaching program that have been run are still in the less category.Things that


need to be developed are related to the physical, technical, and mental development of the athlete.

Keywords: evaluation, CIPP, coaching, archery

\section{PENDAHULUAN}

Olahraga merupakan bagian yang sangat penting dalam pembangunan manusia, baik secara fisik maupun secara mental. Olahraga prestasi merupakan salah satu bidang yang mendapat perhatian khusus oleh pemerintah. Hal tersebut dikarenakan dengan prestasi olahraga yang baik dapat dikatakan sebagai salah satu indikator keberhasilan pembangunan di suatu Negara. Prestasi dalam bidang olahraga harus diprogramkan melalui program yang disusun sedemikian rupa. Pembinaan dilaksanakan harus berkesinambungan dan dalam waktu yang terprogram serta memiliki sasaran yang jelas. Dijelaskan pula komponen di dalam sistem pembinaan olahraga nasional adalah (1) tujuan, manajemen, (3) faktor ketenagaan, (4) atlet, (5) sarana dan prasarana, (6) struktur dan isi program, (7) sumber belajar, (8) metodologi, (9) evaluasi dan penelitian, serta (10) dana (Harsuki, 2012: 37).

Salah satu cabang olahraga prestasi yang sedang berkembang di Bali adalah cabang olahraga panahan. Karakteristik olahraga panahan adalah melepaskan anak panah melalui lintasan tertentu menuju sasaran pada jarak tertentu. Teknik memanah yang tepat dan benar dapat menciptakan teknik memanah yang konsisten.Teknik memanah yang konsisten apabila dilakukan secara terus menerus, maka akan menghasilkan kemampuan teknik memanah yang baik yang berimplikasi pada prestasi dalam memanah. Hal ini juga dikemukakan oleh Mc Kinney sebagai berikut, "In archery everything is so simple. There is no complicated motion. So, it is not very difficult for you to act the same all the time. You will be able to shoot 1440 if you repeat 144 times, this same motion exactly" (Kisik Lee and Robert de Bondt, 2005: 17). Raihan terbaik yang bisa diraih tim panahan Bali pada ajang PON XVIII tahun 2012 di Riau adalah 2 medali perak. Dengan raihan itu Cabor Panahan menjadi salah satu Cabor unggulan di KONI Bali yang diharapkan bisa mendulang medali pada ajang PON XIX di Bandung. Namun, pada ajang PON XIX di Bandung, atlet panahan Bali tidak bisa meraih medali. Ketidakberhasilan itu tentunya perlu mendapat perhatian yang serius dari semua pihak. Selama ini pembinaan Cabor Panahan dilakukan pada tingkat Pengcab/Pengkot, munculnya atlet-atlet berbakat tidak akan lepas dari proses pembinaan yang berkesinambungan. Selain itu, perlu dilakukan evaluasi terhadap program pembinaan untuk melihat tingkat keberhasilan program.

Evaluasi adalah suatu usaha untuk mengukur dan sumber nilai secara objektif dari pencapaian hasilhasil yang direncanakan sebelumnya, dimana hasil evaluasi tersebut dimaksudkan menjadi umpan balik untuk perencanaan yang akan dilakukan di depan (Yusuf, 2008: 3). Evaluasi itu merupakan salah satu fungsi atau unsur manajemen, untuk perbaikan fungsi atau sosial manajemen lainnya, yaitu perencanaan. Evaluasi berusaha mengidentifikasikan mengenai apa yang sebenarnya yang terjadi pada pelaksanaan atau penerapan program. Boyle (dalam Suharto, 2005: 120) menyatakan evaluasi bertujuan untuk (1) mengidentifikasikan tingkat 
pencapaian tujuan, (2) Mengukur dampak langsung yang terjadi pada kelompok sasaran, (3) mengetahui dan menganalisa konsekuensi-konsekuensi lain yang mungkin terjadi diluar sosial. Evaluasi selalu dilaksanakan dengan merujuk kepada tujuan yang ingin dicapai dalam suatu kegiatan. Oleh karena itu, selain pembinaan yang berkesinambungan perlu juga adanya evaluasi yang dilakukan di tingkat Pengcab/Pengkot untuk melihat bagaimana pembinaan dan pemasalan Cabor Panahan, sehingga akar permasalahan prestasi Panahan di Bali dapat di analisis.

Salah satu model evaluasi yang dapat digunakan yaitu CIPP (Context, Input, Process, Product). Model ditinjau dari tahapan-tahapan context, input, process, dan product. Stufflebeam (2003: 2), mengemukakan model evaluasi CIPP yaitu model evaluasi yang terdiri dari empat komponen evaluasi yaitu konteks, input, proses, dan produk. Pengertian evaluasi context, input, process, dan product tersebut lebih rinci dijelaskan dalam Arikunto, Suharsimi dan Lia Yuliana (2008: 46) sebagai berikut. Pertama, evaluasi context adalah upaya untuk menggambarkan dan merinci lingkungan, kebutuhan yang tidak terpenuhi, populasi dan sampel yang dilayani, dan tujuan. Kedua, evaluasi input merupakan evaluasi yang bertujuan menyediakan informasi untuk menentukan bagaimana menggunakan sumber daya yang tersedia dalam mencapai tujuan program. Ketiga, evaluasi process merupakan evaluasi yang dirancang dan diaplikasikan dalam praktik implementasi kegiatan, mengidentifikasi permasalahan prosedur baik tata laksana kejadian dan aktivitas. Keempat, evaluasi product merupakan kumpulan deskripsi dan "judgement outcomes" dalam hubungannya dengan context, input, dan process, terkait dengan perencanaan, pelaksanaan, dan keberhasilan kegiatan.

Penelitian ini bermanfaat sebagai acuan untuk memberikan rekomendasi dalam hal peningkatan pembinaan Cabor Panahan di kabupaten/kota seBali. Dengan adanya evaluasi yang dilakukan dapat mengetahui kelemahan dan kekurangan program pembinaan yang selama ini telah dilaksanakan. Selain itu, hasil penelitian ini dapat digunakan sebagai solusi pemecahan masalah dari kekurangan program pembinaan yang sudah berjalan. Bagi pengcab kabupaten/kota Perpani dan Pengprov Perpani Bali, hasil penelitian ini dapat dijadikan sebagai bahan pertimbangan dan saran untuk perbaikan program pembinaan selanjutnya.

\section{METODE}

Penelitian ini adalah penelitian evaluasi yang menggunakan metode kombinasi kuantitatif dan kualitatif. Metode kombinasi ini menggabungkan pendekatan kualitatif dan kuantitatif ke dalam metodologi penelitian. Sugiyono (2011: 404) menyatakan bahwa metode penelitian kombinasi adalah suatu metode penelitian yang mengombinasikan atau menggabungkan antara metode kuantitatif dan metode kualitatif untuk digunakan secara bersama sama dalam suatu kegiatan penelitian sehingga, diperoleh data yang lebih komprehensif, valid, reliabel, dan objektif. Model yang digunakan dalam penelitian ini adalah model evaluasi CIPP (context, input, process, product). Model CIPP dapat memberikan manfaat untuk melihat apakah program telah berjalan sesuai dengan yang direncanakan atau diinginkan dan menghasilkan produk sesuai dengan yang direncanakan. 
Penelitian ini dilakukan di Provinsi Bali pada 9 (sembilan) Pengcab Perpani kabupaten/kota yaitu Pengcab Perpani Kabupaten Badung, Kabupaten Bangli, Kabupaten Buleleng, Kabupaten Gianyar, Kabupaten Jembrana, Kabupaten Karangasem, Kabupaten Klungkung, Kabupaten Tabanan, dan Kota Madya Denpasar. Penelitian dilakukan dari bulan Mei sampai dengan September 2018.

Subjek Penelitian

Subjek penelitian ini adalah atlet, pelatih, orang tua atlet, pengurus Perpani kabupaten/kota se-Bali yang berjumlah 72 orang. Semua subjek dalam penelitian ini adalah subjek yang dianggap mengetahui tentang program pembinaan prestasi yang ada di kabupaten/kota masing-masing dengan lamanya di panahan minimal 1 (satu) tahun.

Instrumen berupa angket ditujukan pada pelatih, atlet, pengurus Perpani kabupaten/kota se-Bali, dan orang tua atlet dibuat sendiri oleh peneliti. Angket telah divalidasi secara konteks oleh ahli panahan, ahli ilmu keolahragaan, ahli fisiologi olahraga dan organisasi olahraga. Berdasarkan hasil uji coba angket didapat reliabilitas angket sebesar 0,999. Sebelum pengisian angket dilakukan wawancara dengan pengurus pengcab Perpani masing-masing kabupaten/kota.

Teknik analisis data yang digunakan dalam penelitian evaluasi ini adalah analisis deskriptif kuantitatif dan kualitatif, dengan mendeskripsikan dan memaknai data dari tiap-tiap komponen yang dievaluasi baik data kuantitatif maupun data kualitatif. Data dari instrumen angket dianalisis dengan cara kuantitatif dan data dari hasil wawancara akan dianalisis secara kualitatif.
HASIL DAN PEMBAHASAN

Evaluasi Program Pembinaan Prestasi Cabang Olahraga Panahan di Bali dalam Dimensi Context.

Hasil penelitian pada dimensi context dari wawancara kepada pengurus dan pelatih didapat hasil bahwa, masing-masing Pengcab Perpani Kabupaten/Kota yang ada di Bali memiliki program pembinaan tiap tahunnya dan tujuan dari program pembinaan tersebut mampu meraih prestasi pada ajang kejuaraan daerah yaitu Pekan Olahraga Provinsi (Porprov) Bali. Dari 9 (sembilan) Pengcab Perpani Kabupaten/Kota yang ada di Bali, 5 (lima) Pengcab Perpani Kabupaten/Kota saja yang menargetkan progam pembinaan mereka pada ajang yang lebih tinggi yaitu mampu meraih prestasi pada tingkat nasional dan international, diantaranya Pengcab Perpani Kabupaten Badung, Pengcab Perpani Kota Denpasar, Pengcab Perpani Kabupaten Karangasem, Pengcab Perpani Kabupaten Bulelelng, dan Pengcab Perpani Kabupaten Tabanan.

Hal ini didukung oleh antusias masing-masing Pengcab Perpani Kabupaten/Kota tersebut dalam membina atlet. Masing-masing Pengcab Perpani Kabupaten/Kota memiliki atlet binaan pada tiap divisi dalam olahraga panahan. Atlet-atlet binaan Pengcab Perpani Kabupaten/Kota tersebut pernah tergabung dalam Tim Pekan Olahraga Nasional XIX di Jawa Barat untuk membela Provinsi Bali. Selain itu, Pengcab Perpani Kabupaten/Kota tersebut memiliki pelatih lebih dari 1 (satu) orang. Dukungan orang tua juga memberi dampak yang positif dalam pembinaan di masing-masing Pengcab Perpani Kabupaten/Kota tersebut.

Disisi lain, Pengcab Perpani Kabupaten/Kota yang ada di Bali memiliki permasalahan mendasar yang 
sama yaitu belum tersedianya tempat latihan khusus olahraga panahan dengan spesifikasi panjang lapangan minimal 100 meter. Selain itu, pemenuhan sarana berupa peralatan memanah pada masing-masing divisi masih belum memadai, dukungan dana pembinaan dari pemerintah juga masih belum optimal, dan masih minimnya kegiatan pelatihan pelatih yang diselenggarakan oleh Perpani pusat ataupun provinsi mengakibatkan kualitas keilmuan pelatih kurang mumpuni untuk mencetak atlet-atlet yang berprestasi. Permasalahan tersebut paling dirasa oleh Pengcab Perpani Kabupaten/Kota yang belum mampu mencetak atlet untuk dapat bersaing di tingkat Nasional. Oleh sebab itu, masih diperlukannya perbaikan pada berbagai sektor seperti manajemen pengelolaan, pemenuhan sarana prasarana, kualitas SDM dan pendukung, serta anggaran untuk pembinaan. Keempat sektor tersebut merupakan hal yang perlu dibenahi guna mencapai target program pembinaan yang telah dibuat.

\section{Evaluasi Program Pembinaan Prestasi Cabang Olahraga Panahan di Bali dalam Dimensi Input.}

Dimensi input bagi atlet/orang tua, pelatih dan pengurus Pengcab PERPANI Kabupaten/Kota di Bali terdiri dari 8 (delapan) aspek yaitu aspek dukungan lingkungan terhadap pengcab, aspek karakteristik atlet, aspek karakteristik pelatih, aspek organisasi penyelenggara, aspek program latihan, aspek sarana prasaran, aspek pendanaan, dan aspek dukungan orang tua. Gambaran perbedaan hasil evaluasi program pembinaan prestasi cabang olahraga panahan di Bali pada masingmasing aspek dalam dimensi input dapat dilihat dari gambar 1.

Berdasarkan hasil survei yang dilakukan di 9 (sembilan) Pengcab
Perpani Kabupaten/Kota terhadap atlet, pelatih, pengurus dan orang tua talet diketahui bahwa, dukungan lingkungan terhadap keberadaan Pengcab Perpani Kabupaten/Kota yang ada di Bali ratarata dikategorikan cukup. Hal ini dapat dilihat dari dukungan masyarakat dilingkungan Pengcab Perpani Kabupaten/Kota termasuk orang tua atlet juga memberi dukungan yang positif pada setiap kegiatan yang dilakukan Pengcab Perpani Kabupaten/Kota baik aktifitas latihan maupun kejuaraan. Begitu juga dari pihak sekolah yang siswanya merupakan atlet panahan selalu mendukung dengan memberikan dispensasi saat mengikuti kejuaraan panahan dan memberikan apresiasi kepada atlet/siswa yang mendapatkan prestasi baik di tingkat daerah, nasional dan internasional.

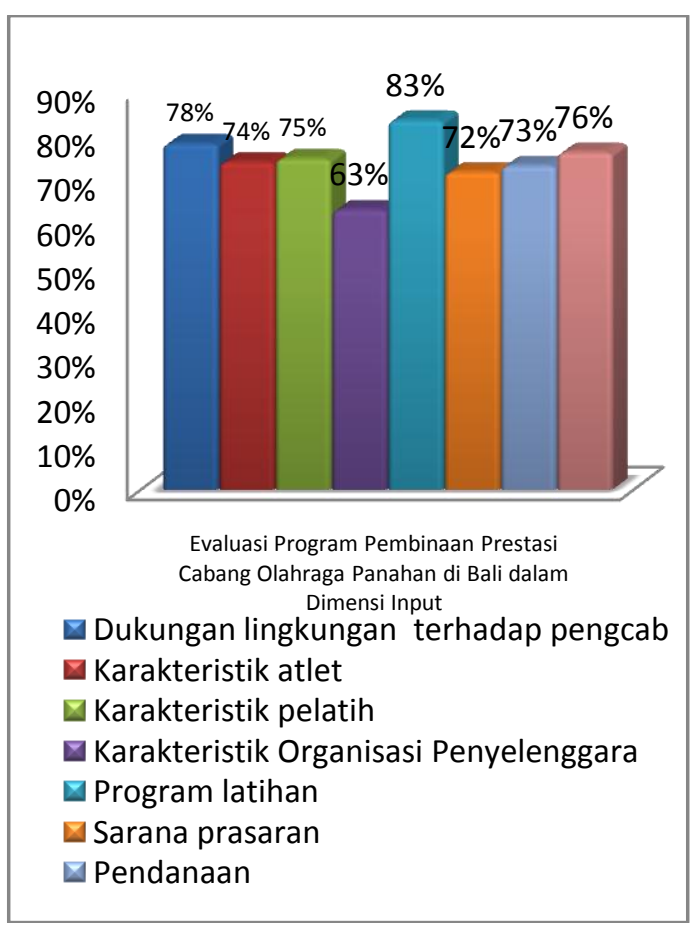

\section{Gambar 1. Dimensi Input}

Namun disamping dukungan positif yang telah diberikan lingkungan terhadap Pengcab Perpani Kabupaten/Kota di Bali masih terdapat beberapa kekurangan dan kendala yang 
dialami. Beberapa kendala yang dihadapi yaitu minimnya dukungan induk organisasi olahraga (KONI kabupaten/kota) dalam hal penyediaan sarana latihan berupa alat panah khususnya di Kabupaten Jembrana, Tabanan, Gianyar, Klungkung, Bangli, dan Karangasem. Sehingga Pengcab Perpani Kabupaten/Kota tersebut tidak bisa melatih atlet-atlet mereka dengan optimal, begitu juga atlet tidak bisa berlatih secara optimal dikarenakan kurangnya sarana berupa alat panahan untuk latihan.

Masing-masing Pengcab Kabupaten/ Kota di Bali mulai membina atlet dari usia minimal 7 tahun hingga 18 tahun ke atas. Artinya tidak ada batasan usia bagi yang ingin berlatih panahan. Seluruh Pengcab Perpani Kabupaten/Kota yang ada di Bali sudah mulai menerapkan regenerasi atlet dengan mulai melatih atlet sejak usia dini dengan melakukan observasi awal terhadap kemapuan dan potensi yang dimiliki masing-masing atlet. Atlet disetiap Pengcab Kabupaten/Kota di Bali memiliki motivasi yang tinggi untuk berlatih, hal ini dapat dilihat dari atlet datang kelapangan sebelum jam latihan atau tidak terlambat, atlet memiliki jadwal latihan diluar jadwal resmi seperti latihan fisik dan drill di rumah masingmasing.

Namun, tidak semua atlet bisa mengikuti latihan yang diberikan setiap 3-4 kali dalam seminggu dikarekan kebanyakan atlet masih berstatus pelajar, dengan waktu sekolah yang berbeda-beda dan tugas-tugas sekolah yang harus mereka kerjakan. Selain itu, masih terdapat kekurangan dari segi jumlah atlet yang dibina pada tiap divisi. Pengcab Perpani Kabupaten/Kota tidak memiliki lebih dari 3 (tiga) orang atlet putra mau pun putri pada divisi standar bow, divisi recurve, dan divisi coimpound. Hal ini paling dirasa oleh Pengcab Perpani Kabupaten/Kota yang tidak mendapat dukungan penuh dalam hal penyediaan sarana latihan. Mengingat masingmasing divisi dalam kejuaraan panahan memiliki kategori beregu yang terdiri dari 3 (tiga) orang pemanah, maka minim setiap Pengcab Perpani Kabupaten/Kota memiliki 3 (tiga) orang atlet pada masing-masing divisi.

Data yang berkaitan dengan karakteristik pelatih dapat digambarkan bahwa, pengcab Perpani Kabupaten/Kota tidak memiliki pelatih lebih dari 3 orang yang mana sebagian besar pelatih merupakan mantan atlet panahan dan telah mempunyai pengalaman melatih minimal 1 tahun pada cabor panahan. Namun tidak semua pelatih mempunyai dasar pelatihan pelatih panahan dan juga pelatihan kondisi fisik dasar karena minimnya keterlibatan pelatih dalam mengikuti pelatihan pelatih fisik maupun panahan. Hal ini disebabkan tidak adanya pelatihan pelatih panahan dan kondisi fisik dasar yang diadakan di Bali. Kebanyakan pelatihan pelatih panahan dan kondisi fisik diadakan di luar Bali, sehingga keterbatasan biaya untuk mengikuti pelatihan tersebut menjadi kendala.

Pada pengambilan data tentang organisasi di dapat bahwa pembentukan Pengcab Perpani kabupaten/kota di Bali sudah berdasarkan AD/ART Perpani pusat dengan struktur organisasi yang jelas untuk menyelenggarakan kegiatan pembinaan. Pengcab Perpani kabupaten/kota di Bali juga menjalin koordinasi dengan institusi pemerintah terkait seperti Disdikpora Kabupaten. Namun masih ada beberapa Pengcab yang pengurus tidak bekerja sesuai dengan tupoksi masing-masing. Namun ini tidak memberi dampak yang berarti 
bagi perkembangan panahan di daerah masing-masing.

$\begin{array}{lrr}\text { Pada aspek } & \text { program latihan } \\ \text { pelatih disetiap } & \text { kabupaten/kota }\end{array}$ mempunyai program latihan dalam proses melatih dengan membuat rumusan tujuan latihan di dalam program latihan walaupun dalam bentuk yang sederhana. Materi latihan fisik maupun teknik yang dirancang disesuaikan dengan kebutuhan atlet dan program latihan yang dibuat telah memenuhi prinsip pelatihan. Pelatih juga merancang try out di dalam program latihan walaupun try out yang dilakukan hanya sebatas antar kabupaten/ kota yang ada di Bali. Namun pelaksanaan try out ini tidak bisa berjalan secara maksimal dikarenakan minimnya even kejuaraan panahan yang diadakan di Bali. Hingga saat ini dalam satu tahun hanya tercatat satu even kejuaraan panahan yang diadakan oleh Pengcab Perpani Kabupaten Badung.

Pada aspek sarana prasarana masih tergolong minim. Sebagian besar Pengcab Perpani Kabupaten/Kota di Bali masih belum memiliki lapangan khusus panahan. Tempat latihan yang digunakan selama ini sudah mendukung keberlangsungan proses latihan, hanya saja masih harus berbagi dengan cabang olahraga yang lain sehingga latihan tidak bisa dilakukan dengan optimal. Disamping itu ketersediaan sarana yang dituntut dalam latihan belum terpenuhi secara keseluruhan, jumlah alat yang tersedia masih belum memenuhi rasio atlet dengan alat. Tetapi, keterpakaian sarana prasarana yang ada sesuai dengan kebutuhan atlet dan juga peralatan latihan yang tersedia telah memenuhi standar masing-masing divisi.

Aspek pendaaan ini merupakan aspek yang paling mempengaruhi dalam proses pembinaan prestasi di tiap-tiap kabupaten/kota. Kerja sama yang baik dilakukan antara pengurus pengkab dengan pihak terkait yang membiayai keberadaan pengkab walaupun pendanaan yang diberikan belum mampu memenuhi kebutuhan masingmasing Pengcab. Disamping itu, sebagian besar Koni kabupaten/kota tidak memiliki anggaran tambahan dana untuk pelaksaan kejuaraan atau mengikuti kejuaraan ditingkat daerah hingga tingkat nasional. Sehingga pengalaman bertanding atlet kurang yang berdampak pada mental bertanding atlet. Selain tidak adanya pendaan dari sisi keterlibatan dalam even kejuaraan, tambahan dana untuk mengikuti pelatihan pelatih dan pelatihan wasit juga dirasa minim. Hal ini menyebabkan tidak adanya pembaharuan informasi bagi para pelatih dan wasit. Untuk itu perlu adanya workshop atau pelatihan pelatih dan wasit cabang olahraga panahan yang di adakan di Bali, sehingga biaya yang dikeluarkan tidak besar

Aspek dukungan orang tua pada setiap pengcab Perpani Kabupaten dapat dikatakan cukup baik.Hal ini dapat dilihat dari dukunga orang tua yang positif dengan mengantar, menemani anaknya untuk latihan panahan dan mempersiapkan keperluan latihan panahan.Disamping itu para orang tua juga melakukan komunikasi yang baik dengan pelatih dan pengurus terkait dengan perkembangan anaknya.Para orang tua juga melakukan komunikasi yang baik tentang latihan yang telah dilakukan oleh anaknya dan juga memberikan motivasi yang positif pada anaknya.Walaupun ada beberapa orang tua atlet yang tidak memberi dukungan secara penuh namun pendampingan dari pelatih dan pengurus pengcab mampu mengatasi masalah ini. 
Evaluasi Program Pembinaan Prestasi Cabang Olahraga Panahan di Bali dalam Dimensi Process

Evaluasi Program Pembinaan Prestasi Cabang Olahraga Panahan di Bali dalam dimensi process terdiri dari 5 (empat) aspek yaitu aspek penseleksian, aspek pengorganisasian atlet dan pelatih, aspek pelaksanaan latihan, dan aspek evaluasi pelatihan/monev.Berikut deskripsi data hasil evaluasi dari masing-masing aspek dapat dilihat pada gambar 2 .

Pada aspek penseleksian atlet maupun pelatih, walaupun tiap Pengkab Perpani Kabupaten/Kota telah melaksanakan proses penseleksian atlet maupun pelatih yang dilakukan sebelum masuk/ terpilih mewakili pengkab dalam even kejuaraan, namun Pengkab Perpani Kabupaten/Kota di Bali belum memiliki pedoman penseleksian atlet maupun pelatih yang ditetapkan secara bersama-sama. Selama ini proses penseleksian hanya berdasarkan kebijakan ketua bersama dengan pelatih Pengkab Perpani Kabupaten/Kota yang menjabat pada saat itu, sehingga kebijakan yang ditetapkan berbedabeda.

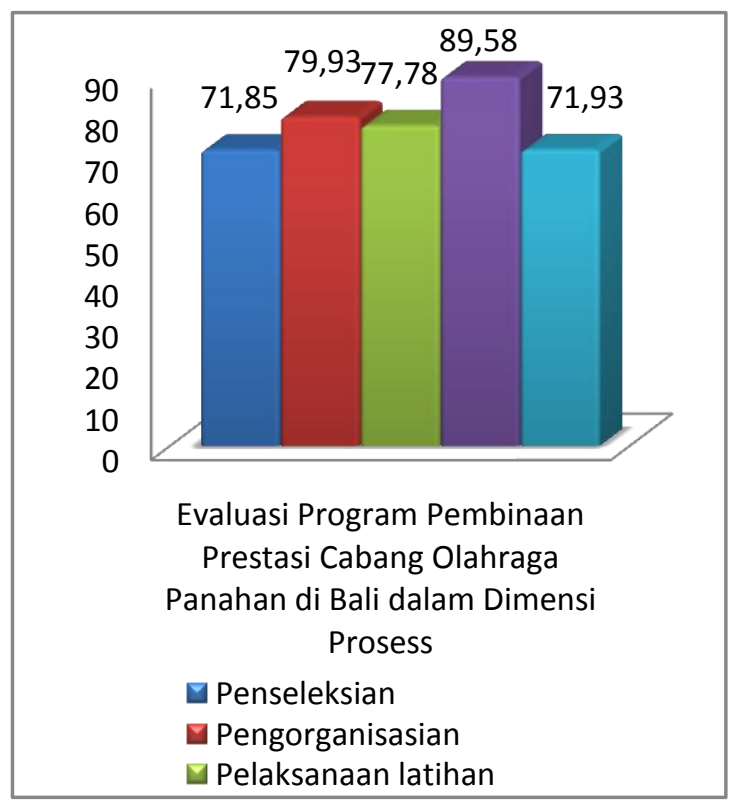

Gambar 2. Dimensi Proses
Pada aspek pengorganisasi atlet dan pelatih telah berjalan cukup baik. Hal-hal yang perlu dibenahi dan ditingkatkan kembali adalah proses perijinan/ dispensasi atlet yang masih berstatus pelajar/mahasiswa dalam mengikuti even kejuaraan atau mengikuti persiapan kejuaraan. Begitu juga dispensasi pelatih di tempat mereka bekerja. Perlu juga lebih banyak diagendakan pertemuan rutin antara penyelenggara pengkab, orang tua, pelatih dan sekolah sehingga segala kemajuan, prestasi dan kendala yang dihadapi dapat di bahas bersama sehingga dapat dicarikan solusinya.

Pada aspek pelaksanaan latihan juga masuk dalam kategori cukup baik. Pelaksanaan latihan dapat berjalan cukup baik, meskipun masih banyak ditemukan kekurangan dalam hal kesiapan pengurus dalam menyiapkan peralatan yang bisa dipakai baik oleh atlet pemula maupun atlet senior. Adapun di beberapa kabupaten seperti, Kab. Badung, Kab. Buleleng, Kota Denpasar, dan Kab. Karangasem memiliki cukup peralatan untuk disalurkan kepada atlet namun kondisi peralatan latihan rata-rata sudah cukup lama, sehingga perlu dilakukan peremajaan peralatan yang dimiliki oleh pengcab kabupaten/kota.

Pemantauan dari pihak penyelenggara terhadap kehadiran atlet tidak dilakukan dengan baik dikarenakan pengurus masih memiliki kesibukan pekerjaan masing-masing, sehingga proses pemantauan atlet tidak berjalan dengan baik. Hal tersebut dapat dilihat pada saat pelaksanaan latihan tidak dilakukan absensi kehadiran sehingga kehadiran peserta tidak terpantau selama proses latihan. Dalam hal evaluasi juga perlu mendapat perhatian, pelatih tidak melakukan evaluasi secara berkala, sehingga penurunan dan kemajuan yang terjadi 
tidak bisa terpantau dan tidak mendapatkan perhatian dari pelatih. Evaluasi yang dilakukan oleh pihak penyelenggara terhadap pelatih juga perlu dilakukan sehingga pelatih benarbenar melakukan tugas nya dengan baik.

\section{Evaluasi Program Pembinaan Prestasi Cabang Olahraga Panahan di Bali dalam Dimensi Product}

Dimensi Product bagi atlet/orang tua, pelatih dan pengurus Pengcab Perpani kabupaten/kota terdiri dari 4 (empat) aspek yaitu aspek perkembangan fisik/fisiologis, aspek perkembangan teknik, aspek perkembangan mental, dan aspek perkembangan prestasi. Berikut deskripsi data evaluasi hasil penelitian dari masing-masing aspek dapat dilihat pada gambar 3.

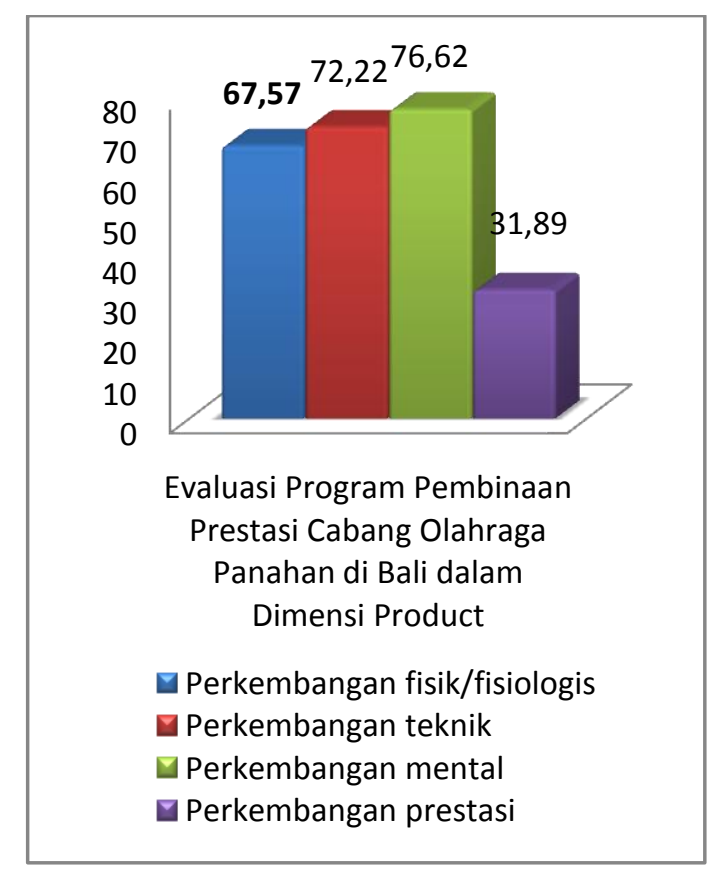

\section{Gambar 3. Dimensi Product}

Pada aspek perkembangan fisik, atlet merasakan ada perubahan fisik/ fisiologis setelah latihan, hal tersebut dapat di dilihat dari hasil tes fisik atlet mengalami peningkatan, sehingga dapat dikatakan program yang dilaksanakan oleh pelatih berhasil meningkatkan kemampuan fisik atlet, akan tetapi peningkatan tersebut masih belum maksimal sehingga belum mampu untuk menunjang pencapaian prestasi atlet bali di daerah, nasional dan internasional.

Dari aspek perkembangan teknik dapat dikatakan sudah cukup bagus, atlet dapat mengikuti tuntutan latihan teknik panahan yang diberikan oleh pelatih. Keterampilan atlet juga mengalami peningkatan dibandingkan pad saat awal. Meskipun dibeberapa kabupaten score penilaian untuk teknik panahan masih kecil, hal tersebut bisa dikarenakan kemampuan pelatih masih di tahap pelatih dasar, sehingga kemampuan untuk menyempurnakan teknik dasar atlet masih kurang. Perkembangan teknik atlet seharusnya selalu mengacu pada hasil evaluasi pelatih, akan tetapi di beberapa kabupaten pelatih tidak melakukan evaluasi terhadap perkembangan teknik atlet. Hal tersebut menyebabkan perkembangan teknik atlet tidak mengalami peningkatan.

Pada aspek perkembangan mental dapat di analisa bahwa atlet memiliki rasa percaya diri yang cukup ketika menghadapi latihan atau pertandingan, dalam prosesnya latihan tidak hanya dilakukan untuk melatih teknik dan fisik saja akan tetapi pelatih juga memberika waktu untuk melatih mental atlet sehingga atlet siap menghadapi segala kemungkinan yang terjadi pada saat pertandingan. Sikap mental yang diharapkan dimiliki oleh seorang atlet adalah disiplin, motivasi tinggi, control diri, optimis, berpikir positif, tanggung jawab, dan tentunya sikap sportifitas. Atlet masih memiliki rasa takut dan ragu-ragu saat menghadapi latihan atau pertandingan dapat dilihat dari jawaban pada angket atlet dengan persentase $55.56 \%$. Atlet mampu berkomunikasi 
baik dengan sesama atlet, orang tua, pelatih, dan pengurus pengkab/kot, hal tersebut dapat membantu mengurangi rasa takutdan ragu-ragu saat pertandingan.

Pada aspek perkembangan prestasi dapat dilihat pada gambar 3 . Berdasarkan gambar diagram tersebut dapat disimpulkan bahwa perkembangan prestasi masih sangat kurang, hal tersebut dapat dilihat dari hasil anggket evaluasi yang diisi oleh pelatih dan pengurus. Prestasi untuk atlet panahan kabupaten/kota berdasarkan hasil evaluasi pada divisi standard bow tingkat daerah cukup merata. Akan tetapi untuk prestasi di tingkat nasional hanya atlet panahanKabupaten Badung, Kabupaten Karangasem, dan Kota Denpasar saja yang berhasil memperoleh medali di event tingkat Nasional.

Untuk prestasi atlet divisi recurve tingkat daerah hanya Kabupaten Badung, Kabupaten Buleleng, dan Kota Denpasar yang bersaing. Namun untuk tingkat Nasional hanya atlet dari kabupaten Badung, dan kota Denpasar saja yang sudah pernah membawa medali. Namun belum ada atlet Bali yang juara di tingkat Internasional.

Untuk prestasi atlet divisi compound tingkat daerah ada beberapa kabupaten yang menjadi langganan juaranya, diantaranya Kabupaten Badung, Kabupaten Buleleng, Kabupaten Karangasem dan Kota Denpasar. Namun untuk tingkat Nasional hanya atlet dari Kabupaten Badung, dan Kabupaten Buleleng saja yang sudah pernah membawa medali. Untuk divisi compound masih belum ada atlet Bali yang juara di tingkat Internasional.

\section{SIMPULAN DAN SARAN Simpulan}

Berdasarkan hasil evaluasi dengan wawancara dan angket untuk atlet, pelatih, pengurus serta orang tua alet dapat ditarik kesimpulan sebagai berikut.

Pada dimensi context, program yang dibuat oleh masing-masing Pengcab Perpani Kabupaten/Kota di Bali sudah sesuai dengan tingkat kebutuhan masyarakat. Dari 9 (sembilan) Pengcab Perpani Kabupaten/Kota yang ada di Bali 5 (lima) Pengcab Perpani Kabupaten/Kota yang menargetkan progam pembinaan mereka pada ajang yang lebih tinggi yaitu mampu meraih prestasi pada tingkat Nasional dan International. Dengan demikian, diperlukannya adanya kerjasama antara pemerintah daerah dan masyarakat untuk berperan serta katif dalam mendukung keberadaaan Pengcab Perpani Kabupaten/Kota di Bali, sehingga Pengcab Perpani Kabupaten/Kota di Bali benar-benar bisa menjadi sentra pembibitan cabang olahraga panahan di Bali.

Pada dimensi input, di masingmasing Pengcab Perpani Kabupaten/Kota yang ada di Bali masuk dalam kategori cukup baik. Hal-hal yang perlu dikembangkan adalah pemenuhan sarana dan prasarana latihan berupa tempat latihan khusus olahraga panahan dengan spesifikasi panjang lapangan minimal 100 meter, peralatan memanah pada masing-masing divisi serta sarana pendukung seperti bantalan dan jagrag.

Pada dimensi procces pelaksanaan program mulai dari penyeleksian atlet, pengorganisasian, pelaksanaan latihan, program latihan, dan evaluasi/monev masuk dalam kategori cukup baik. Ada beberapa hal yang perlu dikembangkan yaitu 
peningkatan kualitas pelatih dan wasit dimasing-masing Pengcab Perpani Kabupaten/Kota melalui penataran pelatihan pelatih dan wasit panahan.

Pada dimensi product, hasil yang didapat dari program pembinaan yang telah dijalankan masih dalam kategori kurang.Hal yang perlu dikembangkan berkaitan dengan perkembangan fisik, teknik dan mental atlet.

\section{Saran}

Berdasarkan hasil analisis data, pembahasan dan kesimpulan, dapat diberikan beberapa saran rekomendasi terkait dengan program pembinaan Pengcab Perpani Kabupaten/Kota di Bali sebagai berikut.

Pelaksanaan rekrutmen atau proses seleksi atlet yang akan mewakili Pengcab Perpani Kabupaten/Kota dalam even kejuaraan harus dilakukan dengan mekanisme yang telah disepakati secara terbuka dan transparan. Rekrutmen atau seleksi yang benar akan diperoleh atletatlet potensial.

Pengadaan sarana dan prasarana diharapkan benar-benar sesuai dengan standarisasi cabang olahraga panahan.Khusus untuk tempat latihan setiap Pengcab Perpani Kabupaten/Kota diharapkan memiliki tempat latihan yang khusus agar atlet dapat berlatih dengan optimal.

Sumber daya manusia harus terus ditingkatkan dengan mengikutsertakan pelatih atau wasit dalam kegiatan penataran di luar daerah dan mengadakan kegiatan penataran pelatih dan wasit di daerah, sehingga makin banyak pelatih dan wasit yang terlibat. Kebutuhan dana dalam pelaksanaan program latihan diharapkan dapat terpenuhi, dengan mencari donatur dari luar kepengurusan. Donatur bisa berasal dari perusahaan di sekitar pengkab/kota,

\section{DAFTAR PUSTAKA}

Arikunto, Suharsimi dan Yuliana, Lia. 2008. Manajemen Pendidikan. Yogyakarta: Aditya Media.

Harsuki. 2012. Pengantar Manajemen Olahraga. Jakarta: PT, Raja Grafindo Persada.

Kisik Lee and Robert de Bondt. 2005.Total Archery, Samick Sports Co,Ltd.

Stufflebeam, D, L. 2003. The CIPP Model for Evaluation: the Article Presented at the 2003 Annual Conference of the Oregon Program Evaluators Network (OPEN) 3 October 2003 (online), (http://www.wmich.edu, diakses 23 Oktober 2013).

Sugiyono. 2011. Metode Penelitian Kombinasi (Mixed Methods). Bandung: Alfabeta

Suharto, Edi. 2005. Analisis Kebijakan Publik, Edisi Revisi. Alfa Beta: Bandung

Yusuf Tayibnapis Farida. 2008. Evaluasi Program dan Instrumen Evaluasi, Untuk Program Pendidikan dan Penelitian. Jakarta: Rineka Cipta. 